\title{
ELECTRONIC LEARNING TOOLS AS A MEANS OF INCREASING THE EFFECTIVENESS OF INCLUSIVE EDUCATION
}

\author{
Guzel Zabirovna Khabibullina ${ }^{1}$ \\ Sergey Vladislavovich Makletsov ${ }^{2}$ \\ Alfira Mazitovna Akhmedova ${ }^{3}$ \\ Mars Zabirovich Khabibullin ${ }^{4}$ \\ Aygul Raisovna Khafizova ${ }^{5}$
}

\begin{abstract}
Today, the education of young people with disabilities is given special attention. Therefore, inclusive education becomes the main focus of teaching such children. It is based on the use of learning technologies allowing for all children to obtain knowledge in ordinary schools, taking into account the peculiarities of their development. This opportunity is provided by the active use of electronic learning tools. Therefore, there is a need to create and implement integrated electronic educational resources that will have the focus of tasks on a specific subject for the purpose of teaching children with special needs. The authors indicate a
\end{abstract}

comparative analysis of thematic sites as one of the leading methods in the study of this problem; the limitedness of use of electronic educational resources in inclusive education was revealed on the basis of this method. The main results of the study include the development of an electronic educational resource on the topic "Number Systems" and methodological recommendations on the organization of the educational process with its use in inclusive education. Their significance lies in the fact that they can be recommended for use by teachers, and can also become a tool for self-study of this topic. The results of the research fill in the existing gaps in the theory of

1 Kazan Federal University, 420008, Kazan, Russia. Tel.: +79274057021, e-mail: hgz1980@ rambler.ru.

${ }^{2}$ Kazan Federal University, 420008, Kazan, Russia.

${ }^{3}$ Kazan Cooperative Institute of the Russian University of Cooperation, 420081, Kazan, Russia.

${ }^{4}$ Tatar encyclopedia Institute and Regional Academy of Sciences, Republic of Tatarstan, 420015, Kazan, Russia.

${ }^{5}$ Kazan Federal University, 420008, Kazan, Russia. 
general education, contribute to the solution of questions about the motivation of teaching computer science to special needs children.

Keywords: e-learning modalities, elearning resource, inclusive education.

\section{Introduction}

In modern society, the teaching process in inclusive education is structured so that the same education is provided to all children by place of residence, regardless of their characteristics, in the same educational institutions that have all the conditions for children and provide individual support to each pupil [3].

The success of classes in an inclusive class depends on certain conditions, the observance of which is fully vested in a teacher: the presence of a clear algorithm for each lesson; the materials to facilitate its understanding should be as clear as possible; each task must meet a specific action algorithm; various activities should be used to avoid satiation of children with monotonous work on the lesson.

Electronic learning tools actively used by teachers help children successfully master learning material and motivate their learning activities [1]. The use of computer-based training programs in the classroom contributes to the acquisition of deeper and higherquality knowledge by pupils, the development of their creative potential, and the development of pupils' motivational readiness to apply their knowledge in real life [2], [8], [10], [11]. Thanks to research in the field of the theory and practice of professional education by such scholars as V.P. Bespalko, P.I. Halperin, T.I. Gergey, as well as works on general pedagogical problems of improving education [7], [9], it made possible to develop issues of computerization in education, which is a logical continuation of the introduction of computer-based training programs into the educational process.

There are special requirements for e-learning modalities intended for teaching children with disabilities: didactic, specific, methodical, and also ergonomic requirements.

The following types of lessons using e-learning modalities are specified: training programs serving as visual aids; a "Diagonal scheme" which implies the availability of several computers and is based on group work; 
practical training based on independent work; and the lessons based on the individual work of a pupil with a training program.

The authors analyzed three different electronic educational resources [4], [5], [6] intended to teach children with disabilities, in order to identify their strengths and weaknesses. The results of the analysis are presented in table 1.

Table 1

\begin{tabular}{|c|c|c|c|}
\hline $\begin{array}{l}\text { Resource } \\
\text { name }\end{array}$ & $\begin{array}{l}\text { Federal Institute } \\
\text { of Pedagogical } \\
\text { Measurements }\end{array}$ & $\begin{array}{l}\text { Federal Center } \\
\text { for Information } \\
\text { and Education } \\
\text { Resources }\end{array}$ & $\begin{array}{c}\text { Center for Inclusive and } \\
\text { Distance Education }\end{array}$ \\
\hline $\begin{array}{l}\text { URL resource } \\
\text { on the web }\end{array}$ & http://www.fipi.ru/ & http://fcior.edu.ru & http://cde.sipkro.ru/moodle/ \\
\hline Description & $\begin{array}{l}\text { This resource is } \\
\text { characterized by } \\
\text { open access to the } \\
\text { necessary } \\
\text { materials } \\
\text { (regulatory } \\
\text { documents, } \\
\text { illustrative } \\
\text { materials, } \\
\text { guidelines, task } \\
\text { bank). }\end{array}$ & $\begin{array}{l}\text { This resource is } \\
\text { characterized by } \\
\text { the availability of } \\
\text { a catalogue and } \\
\text { storage of } \\
\text { electronic } \\
\text { educational } \\
\text { resources for an } \\
\text { open multimedia } \\
\text { environment. }\end{array}$ & $\begin{array}{l}\text { This resource is } \\
\text { characterized by the } \\
\text { availability of a virtual } \\
\text { classroom with training } \\
\text { courses for children with } \\
\text { special needs. }\end{array}$ \\
\hline Advantages & $\begin{array}{l}\text { A variety of tasks } \\
\text { in all academic } \\
\text { subjects, the } \\
\text { presence of } \\
\text { training } \\
\text { collections of }\end{array}$ & $\begin{array}{l}\text { The availability } \\
\text { of digital } \\
\text { materials on the } \\
\text { site. The ability } \\
\text { to search in } \\
\text { sections and in }\end{array}$ & $\begin{array}{l}\text { A variety of training } \\
\text { courses for children with } \\
\text { special needs. }\end{array}$ \\
\hline
\end{tabular}




\begin{tabular}{|l|l|l|l|}
\hline & $\begin{array}{l}\text { examination tasks } \\
\text { for special needs } \\
\text { children. A } \\
\text { separate version of } \\
\text { the site is } \\
\text { developed for the } \\
\text { visually impaired } \\
\text { children. }\end{array}$ & $\begin{array}{l}\text { into account the } \\
\text { age category. } \\
\text { of educational } \\
\text { modules. }\end{array}$ & \\
\hline Disadvantages & $\begin{array}{l}\text { Pupils are not able } \\
\text { to verify the } \\
\text { correctness of } \\
\text { their solution to a } \\
\text { particular task. } \\
\text { Tasks are arranged } \\
\text { randomly and are } \\
\text { repeated in several } \\
\text { sections. }\end{array}$ & $\begin{array}{l}\text { There is a need } \\
\text { to install special } \\
\text { software. The } \\
\text { training material } \\
\text { is located }\end{array}$ & visually impaired pupils \\
randomly. & courses. \\
\hline
\end{tabular}

Thus, the advantages include the content of various topics and sections, the colourful design, the availability of tasks in abilities and materials for children with disabilities. The main disadvantage is the fact that there are no tasks oriented to a specific discipline of teaching children with special needs.

We took into account the analysis carried out above in the process of creating an electronic educational resource on the topic "Number Systems" and developing methodological recommendations for it.

\section{Methods}

The following main stages can be distinguished when developing an electronic educational resource on the topic "Number Systems":

1. Analysis of electronic educational resources that implement the inclusive education principle.

At the first stage, the authors identified the advantages and 
disadvantages of such sites based on the analysis of various electronic educational resources with a view to further understanding them while further implementing the remaining stages of developing an electronic educational resource.

\section{Goal setting.}

The authors identified the main objectives for the implementation of electronic educational resources, the main criteria and means of their evaluation.

3. Determining the structure of the course.

This stage is characterized by the selection of methodological material, developing a detailed structure of the course, learning trajectories, determining ways of interacting with the teacher, and means of learning achievements monitoring.

4. The choice of design.

The choice of design of an electronic educational resource on the topic "Numbering Systems" (window marking, location of the main windows, electronic educational resource navigation, and colour gamut) depends on the imagination and preferences of the resource developer.
5. Selection of tools.

When developing the course, the authors selected the tools for implementing an electronic educational resource, taking into account technical requirements, their own work opportunities on technical equipment and the necessary equipment.

6. Implementation of an electronic educational resource.

Taking into account the above, an electronic educational resource on the topic "Number Systems" is created at the last stage.

\section{Results}

The educational resource developed by us on the topic "Number Systems" includes the following structural elements: main page; theory (theoretical material for studying this topic, as well as a glossary), tasks (practical tasks for sections of the topic), tests (instructions for passing the test and four options for testing pupils' knowledge), a version for the visually impaired pupils (this function converts the appearance of the site so that pupils with special needs find it easier to perceive information). 
This electronic educational resource can not only be used by a computer science teacher at a school to teach children with special needs but can also become a tool for self-study of the topic by children with disabilities. For its use, we have developed guidelines for the organization of the educational process.

\section{Discussion}

The use of this electronic educational resource by a teacher is possible at any type of lessons.

1. A lesson with learning new material. For a teacher, it is necessary to organize the initial consolidation of the material, so in the first part of the lesson, the teacher explains to everyone the new topic, using clarity tools. Then, together with the children, the teacher solves several tasks from the set of practical tasks from the educational resource on the topic "Number Systems".

In the second part of the lesson, to consolidate the knowledge of "ordinary" pupils, they independently solve individual practical tasks from the educational resource on the topic "Number Systems", and the teacher explains the content of a new topic to "special needs" pupils. After that, "special needs" children solve individual tasks, and "ordinary" children check the completed tasks.

The last third part of the lesson involves conducting a final test of tasks and summing up. The teacher clarifies the tasks for homework (it is necessary to read these sections of the resource, to solve the specified practical tasks of the educational resource on this topic). For the "special needs" children, the homework is explained individually by the teacher.

2 The lesson for the formation and consolidation of knowledge and skills. It is conducted to assess the level of knowledge of pupils, and also for making changes in the educational process.

The first part of the lesson involves the repetition of the materials studied: "ordinary" pupils are engaged in a studying the resource (theoretical material, practical tasks of an educational resource on the topic "Number Systems"); and "special needs" children recall the basic concepts of the previous lesson.

In the second part of the lesson, the class is divided into three groups 
according to the ability of pupils (good, mid-level and weak pupils). Each group performs a ten-minute independent task of working with an electronic educational resource. The first group of pupils solves tasks on computers, other groups work with paper textbooks and handouts. The teacher monitors the course of task execution, helps in the event of any difficulties in their solving. The pupils from the first group are replaced by pupils from the second group, who, in turn, are replaced by representatives of the third group.

The final test of completed tasks and summarizing can be attributed to the third part of this lesson. Additional time is devoted to clarifying the homework (it is necessary to read the paragraphs on the studied topic in the electronic educational resource and to solve the proposed practical tasks). It is necessary to individually say to each "special need" child what he/she must perform independently.

3. Knowledge control lesson. Each pupil independently passes his or her own test version of the educational resource on the "Number System" topic. The test option is chosen by the teacher, taking into account the pupil's capabilities. The teacher monitors the process of testing pupils, advising them in case of questions, and speaks individually to each of the pupils on all the errors and methods of their elimination.

\section{Summary}

In this paper, the authors justify the feasibility of using electronic learning modalities in inclusive education. Also, methodological recommendations were developed for the use of electronic educational resources on the topic "Number Systems" for presenting new material, building and securing a system of knowledge and skills, exercising knowledge control, and also for pupils to work independently within the framework of inclusive education.

\section{Conclusion}

In conclusion, we would like to note that the learning process of a particular pupil requires the teacher to use forms and techniques that are appropriate for the child's capabilities, ensuring the preservation and strengthening of his or her psychophysical health and emotional 
stability. It is only when such conditions are created for a child one can say that differentiated and individual approaches for their learning are carried out.

\section{Acknowledgements}

The work is performed according to the Russian Government Program of Competitive Growth of Kazan Federal University.

\section{References}

Akhmedova A.M. Preparation of teachers on physics and computer science to the use of electronic teaching aids / A.M. Akhmedova, G.Z. Khabibullina // UGSS Scientific Notes. Issue 1 (12). - 2014. - p.130-134.

2 Akhmedova A.M. Implementation of the computer tutorial program "Photoshop graphics editor" in the Delphi programming environment / A.M. Akhmedov, G.Z. Khabibullina, I.A. Khuzina // Kazan Pedagogical Journal. - No.1 (132). - 2019. - P.70-74.

3 Pugachev A. S. Inclusive education as a means of integration into the labour activity / A. S. Pugachev // Secondary professional education. - 2012. -No. 7. pp. 5-6.

Federal Institute of Pedagogical Measurements [Digital source]. - Access mode: http://www.fipi.ru/

Federal Center for Information and Educational Resources [Digital source]. - Access mode: http://fcior.edu.ru

Center for Inclusive and Distance Education [Digital source]. - Access mode: http://cde.sipkro.ru/moodle/

Betz, N. Contributions of self-efficacy theory to carer counselling: a personal perspective / N. Betz // The Career Development Quarterly. - 2004. - Vol. 52. - PP. $340-353$.

Khabibullina G.Z., Makletsov S.V., Khairullina L.E. Application of information technologies to improve the quality of mathematical training teachers of natural-science disciplines // International journal of engineering and technology (UAE). - 2018. - Vol.7, Is.4. - P.74-77.

Khabibullina G.Z., Shigapova E.D., Rusanova I.A. The Development of 
Academic Mobility of Students of

Pedagogical Departments in Universities

/ European Proceedings of Social \&

Behavioural Science EpSBS. - 2016. -

Vol. 12. - PP. 83-88

Makletsov S.V., Khabibullina G.Z. Elearning Model for Bachelors, Specializing in Mathematics and IT // The European Proceedings of Social \& Behavioural Science EpSBS. - 2016. Vol. 12. - P. 115-119

Makletsov S.V., Starshinova T.A., Khabibullina G.Z. Formation model of information competence of bachelors specializing in mathematics \& computer sciences // Journal of organizational culture communications and conflict. 2016. - Vol. 20, Sp. issue 2 - P. 173-179. 